\title{
THE INFLUENCE OF PRACTICE METHOD AND ACHIEVEMENT MOTIVATION OF SHOT PUT SKILL
}

\author{
Ucok Hasian Refiater ${ }^{1}$ \\ ${ }^{1}$ Faculty of Sport Science and Health, Univeritas Negeri Gorontalo, Jl. Jend. Sudirman \\ No.6, Dulalowo Tim., Kota Tengah, Kota Gorontalo, Gorontalo 96128 \\ Coressponding author, email : Ucok_Sport@ung.ac.id
}

\begin{abstract}
The aim of this research is to find out influence of practice method and achievement motivation of shot put skill. It was done at Sport Major, Health and Sports Department of State University of Gorontalo. This research uses the experimental method with factorial design $2 \times 2$. The Population are 189 male students of Sport Major, though the sample which is used are 75 secondsemester male students which passed the lecture of Athletic Shot put O'bryn which is divided into four groups, consists of 10 people each. Data Analysis uses the Variants Analysis (Anava) and Tukey Test for the next step. This Research concludes that: (1) There is a significant difference between plyometric and conventional practice method for Shot-Put skill. (2) For the High achievement motivation, plyometric practice method is better than the conventional practice method for the Shot-Put skill. (3) For those who have the lack of achievement motivation, there is no significant difference between plyometric and conventional practice method for the Shot Put skill. (4) There is positive interaction between practice method and achievement motivation for the shot put skill.
\end{abstract}

Keyword: The Influence, Practice Metho, Achievement Motivation, and Shot Put Skill

\section{INTRODUCTION}

Sport is an integral activity of human civilization whose existence is useful for life. By exercising other than a person will be able to maintain his health can also be directed to a higher level that is towards improving achievement. One type of sport is athletics that we do not realize the movements we have done in everyday life. The IAAF states that athletics will always be related to race and achievement and both are basic aspects of participation in sports. Success at the individual level requires high qualities such as strength, endurance, speed, coordination and techniques that must be learned and practiced.

Shot put is the ability of individuals to display object / bullet reject movements to reach distances as far as possible with the following sequence of techniques; attitude of preparation, gliding, rejecting and final attitude (continued movement). To produce 
optimal performance in Shot Put must be supported by several components including: quality coaches, talented athletes, correct training programs, good physical condition, excellent mental health and proper training methods. The effort to give birth to high achievers is not easy, but requires time and involves various components. As for the components that play a role in achievement of achievement according to Harsono (1988) there are four factors that influence in getting sports achievements, namely (1) physical condition, (2) technique, (3) tactics, (4) psychological. The four components must be given to athletes in a programmed, organized, directed and measured way to get optimal performance.

The method is a concept or form of training that resembles or resembles the situation and condition of activities that often occur in real situations. If you pay attention to the shot put shot in Gorontalo usually use conventional models. The conventional method is an approach that emphasizes weight training that is prevalent by the trainers in Gorontalo especially the bullet trainers. This training method did not contribute to the improvement in the performance of Gorontalo bullets.

Based on the above problem, it is necessary to do research using the training method and achievement motivation for shot put. The method used in this study consists of: plyometric training methods and conventional training methods, while achievement motivation as an independent variable attributes consist of: high and low achievement motivation. Shot put as a dependent variable (devendent variable). The existence of this research is expected to help find a solution in the practice of Shot Putting in Gorontalo.

The term plyometrics comes from the Greek language which consists of the syllable "plyo" means more and "metric" means to measure. The word plyometrik also means "plyethyein" which in English means to inecrease which means to increase or increase. According to Chu (1992) plyometric training methods are exercises that can produce strong muscle contractions with very fast movements. Hazeldyne (1989) said that plyometrics is a form of exercise with increasing athlete quality in the form of power that is carried out explosively with reactive movements seen in our activities. Plyometric training according to Amheim (1985) is a type or form of overloaded isometric exercise, which uses stretch reflexes over myotatic reflex, an eccentric contraction (elongation), 
where the muscles are truly "on stretch" (stretched quickly before concentric contractions (retracts).

Baechle (2002, p.1) said that weight training is training that includes the use of barbells, dumbbells, mechanical equipment and others such as clothes that are weighted, hitters, flexible tubes etc. that are used to improve appearance. Meanwhile, according to Fox (1991) weight training is specifically designed to increase strength, power and muscular endurance. This exercise has a variety of forms that are closely related to muscle movements that are carried out statically or dynamically.

Motivation comes from "movere" which means to move or encourage to move. Motivation is used to show a situation in someone who comes from the consequences of a need; and with this motivation arouses one's behavior toward meeting the needs. Human motivation in meeting needs depends on the hierarchy of needs. Lower needs must be met before moving on to higher needs. These needs determine how people behave and motivate themselves. According sudibyo (1993) motivation is the process of actualizing the source of the driving force and driving individual behavior to meet the need to achieve goals. Likewise, the opinion of Purwanto (1997) motivation is "driving" an effort that is based on influencing a person's behavior so that he is moved to act to do something so as to achieve certain results or goals. Achievement motivation to meet two needs, namely achieving success and avoiding failure. The cause of the urge to do something or act can come from within the athlete (intrinsic) or comes from outside the athlete's self (extrinsic). According to Sudibyo (1989) the achievement motive is the motive that encourages individuals to race against a measure of excellence. While this measure of excellence can be in the form of himself, others, and can also be the perfection of the task.

\section{METHOD}

\section{Research Methods and Design}

The method used in this research is the experimental method. Experiments are activities that are planned and implemented by researchers to collect data that has to do with hypotheses. By involving one independent variable with two levels, namely the plyometric training method and the conventional training method, as well as one 
categorical variable with two levels, namely high motivation and low motivation, and one dependent variable, namely the ability to reject bullets.

The design of this study uses a simple factorial design $2 \mathrm{X} 2$ factorial design is the experimental units into cells in such a random way that each experimental unit in each cell is relatively homogeneous. The $2 \mathrm{X} 2$ factorial design is described as follows: Sudjana (2002)

Table 1: Research Design

\begin{tabular}{lcc}
\hline $\begin{array}{l}\text { Motivation } \\
\text { Achievers }\end{array}$ & $\begin{array}{c}\text { Method of Exercise } \\
\text { (A1) }\end{array}$ & $\begin{array}{c}\text { Conventional } \\
\text { (A2) }\end{array}$ \\
\hline $\begin{array}{l}\text { High Achievement Motivation } \\
\text { (B 1) }\end{array}$ & A1 B1 & A2 B1 \\
$\begin{array}{l}\text { Low Achievement Motivation } \\
\text { (B2) }\end{array}$ & A1 B2 & A2 B2 \\
\hline
\end{tabular}

\section{Place and time of research}

This research will be conducted in the city of Gorontalo on students of the Health Fikk of the State University of Gorontalo. This research is planned to take place for eight weeks, each week meeting Edward L. (1992, p. 143). thus the total number of meetings was 24, with activities including testing of research instruments, taking initial data for sample grouping, conducting experiments and taking final data. The implementation of the experiment lasted for 2 months.

\section{Population and Sampling Techniques}

The population of this research is the male students of the Department of Social and Political Sciences, FIKK State University of Gorontalo in the second and fourth semester. The sample is students who have passed the athletics course with the Rejecting force behind bullet $(\mathrm{O}$, brien / linear style). Thus the sampling technique in this study is a random sampling technique. Randomization is applied to students, the process of dividing two groups between groups that will be given plyometric and conventional training by random means. With the following steps: 1). Divide students randomly into two experimental groups. 2). Perform an achievement motivation test. 3). Arrange 
rankings ranging from high achievement motivation level scores to low achievement motivation scores. 4). The grouping of achievement motivation level scores refers to Verducci's opinion (1980 p.176-177) that the $27 \%$ highest score is a group of students who have a high level of achievement motivation and $27 \%$ the lowest score of a group of students who have a low level of achievement motivation.

\section{Data collection technique}

The data needed in this study is achievement motivation data, and data on the ability to reject bullets. So the instrument that will be used in this research is the Questionnaire to collect achievement motivation data and the Backward ability bullet test (O, Brien / linear style) to collect data on the ability to reject bullets.

\section{Reject Ability Instrument (Y)}

Research instruments to measure the level of motivation using a research questionnaire. Meanwhile, to measure the ability to reject a bullet using a shot put ability test. Inside diameter of shot put circle $2,135 \mathrm{~m}$. This circle is divided into two parts that are bounded or marked by lines of paint drawn through the center of the circle up to 75 $\mathrm{cm}$ on either side of the circle. In the Shot Put field there are repulsion material made of wood or other suitable material in the form of an arch. The inside of the beam is exactly right with the inner turning circle mounted firmly or firmly on the ground $1.22 \mathrm{~m}$ long and $114 \mathrm{~mm}$ wide and $100 \mathrm{~mm}$ thick. And there is the Repulsion Sector, this sector is formed by a line drawn from the center of the circle through the edge of the repulsion boundary beam and forms an angle of 400 sector lines as wide as $5 \mathrm{~cm}$ of throw / repulsion is valid, the bullet must fall first in the throw / repulsion sector.Sasaran penskoran adalah Hasil Tolakan yang syah diukur dengan pita baja (meteran). Angka nol (0) diletakan pada jatuhnya puluru yang paling dekat dengan balok penahan dan meteran ditarik ke titik pusat sektor tolakan serta dibaca hasilnya dalam satuan meter (m) dengan taraf ketelitian sampai dengan $0,1 \mathrm{~cm}$, pada angka yang tepat berada pada balok penahan bagian depan. (PASI, 2000, h.226).

\section{Data Analysis Techniques}


Data obtained in this study will be processed and analyzed using analysis of variance (ANAVA) techniques, two paths, and continued with further tests using the Tukey Test, (Gene V. Glass and Kenneth D. Hopkins, 1984, pp.417-419) because this research is an experimental research with a $2 \times 2$ factorial design, the data analysis uses two-way ANAVA, (Santoso Muwarni, 2001, pp. 60-62) with a confidence level of 0.05. Before the data is processed using analysis of variance (ANAVA), the ANAVA requirements test is carried out, namely the Normality Test using the Lilifors Test, and for the Variance Homogeneity test using the Berleft Test, (Sudjana, 2002.h.367) with a confidence level $=0.05$

\section{RESULTS AND DISCUSSION}

\section{Increased Bullet Resistant Ability Plyometric Exercise Method as a whole}

Data on the overall increase in the ability of the plyometric training method group, obtained a range between 6.72 to 7.84 , obtained an average of 7.27 standard deviations of 0.306. Obtained 50\% (10 people) obtained an increase in the ability to put a shot put above average, 20 (4 people) on average and 30\% (6 people) below average.

\section{Increased Ability to Refuse Bullets Group Overall Conventional Training Methods}

Data on the increase in the ability to reject conventional training methods as a whole, obtained a range between 6.72 to 7.42 , obtained an average of 7.08 standard deviations of 0.204 . Obtained $35.00 \%$ ( 7 people) obtained an increase in the ability to put out a bullet above the average, $20.00 \%$ ( 4 people) on average and $45.00 \%$ (9 people) below average.

Increased Bullet Resistance Ability of High Achievement Motivation Groups with Plyometric Training Methods

Data on the increased ability of shot put on high speed motivation groups using plyometric training methods, obtained a range between 7.19 to 7.84 , obtained an average of 7.48 standard deviations of 0.216 . Obtained 30\% (3 people) obtained an increase in shot put ability above average, $20 \%$ ( 2 people) on average and $50.00 \%$ (5 people) below average.

\section{Increased Bullet Resistance Ability to Achieve Low Achievement Motivation Groups with the Plyometric Exercise Method}


Data on the increased ability of shot put on low-achieving motivation groups using plyometric training methods, obtained a range between 6.72 to 7.46 , obtained an average of 7.07 standard deviations of 0.242 . Obtained $30 \%$ ( 3 people) obtained an increase in shot put ability above average, $30 \%$ ( 3 people) on average and $40 \%$ ( 4 people) below average.

\section{Enhancing the Capability of Bullets with High Achievement Motivation Groups using Conventional Training Methods}

Data on the increase in the ability of shot put on high achievement motivation groups using conventional training methods, obtained a range between 6.72 to 7.32 , obtained an average of 7.04 standard deviations of 0.220 . Obtained $50 \%$ (5 people) get an increase in the ability to put a shot put above average, $10.00 \%$ ( 1 person) on average and $40.00 \%$ (4 people) below average.

\section{Increased Ability to Refuse Bullets with Low Achievement Motivation Groups using Conventional Training Methods}

Data on the increase in the ability of shot put on low achievement motivation groups using conventional training methods, obtained a range between 6.89 to 7.42 , obtained an average of 7.11 standard deviations of 0.194 . Obtained $30 \%$ (3 people) obtained an increase in shot put ability above average, 20\% (2 people) on average and 50\% (5 people) below average.

\section{Testing Requirements Analysis}

Before analyzing the Variant (Anava), the analysis requirements test is first erformed, namely (1) normality test; and (2) population homigenity test.

\section{Normality Test}

The normality score test for increasing shot put ability is done by using Liliefors test at a significant level $\alpha=0.05$.

Table 2: Summary of sample normality test results

\begin{tabular}{ccccc}
\hline Group & $\mathbf{N}$ & $\mathbf{L}_{\mathbf{0}}$ & $\mathbf{L}_{\mathbf{t}}$ & Conclusion \\
\hline 1 & 20 & 0,046 & 0,190 & Normal \\
2 & 20 & 0,113 & 0,190 & Normal \\
3 & 10 & 0,118 & 0,258 & Normal \\
4 & 10 & 0,082 & 0,258 & Normal \\
5 & 10 & 0,156 & 0,258 & Normal \\
\hline
\end{tabular}




\begin{tabular}{lllll}
\hline 6 & 10 & 0,225 & 0,258 & Normal \\
\hline
\end{tabular}

Based on table 2 above, the Lo for all sample groups is smaller than the Lt. Thus it can be concluded that the sample comes from normally distributed populations. Then these results give the implication that parametric statistical analysis can be used to test the hypotheses proposed in this study, so that the first requirement for testing has been fulfilled.

\section{Homogeneity Test}

Homogeneity test of variance for each group data of shot put capability of each treatment using the Barlett test at the significance level $\alpha=0.05$.

Table 3: Summary of homogeneity test results

\begin{tabular}{cccccc}
\hline Group & Variant & $\begin{array}{c}\text { Variant } \\
\text { Combine }\end{array}$ & $\mathbf{X}_{\mathbf{h}}$ & $\mathbf{X}_{\mathbf{t}}$ & Conclusion \\
\hline 1 & 0,22 & & & & \\
2 & 0,24 & 1.73 & 0,45 & 7,81 & Homogen \\
3 & 0,22 & & & & \\
4 & 1,19 & & & & \\
\hline
\end{tabular}

Calculation results as illustrated in table 4.9 above, obtained $\mathrm{X} 2 \mathrm{~h}=0.45$ smaller than $\mathrm{X} 2 \mathrm{t}=7.81$ or $\mathrm{Xh} 2<\mathrm{Xt} 2$, at the significance level $\alpha=0.05$. Thus it can be concluded that all four populations have the same variance (homogeneous).

\section{Hypothesis Testing}

To test the hypotheses of the research conducted by using two-way variance analysis (ANAVA) techniques. The complete ANAVA calculation can be seen in Appendix 9 pages 127-130.

Table 4: Summary of the Anava calculation results

\begin{tabular}{lcrrrrr}
\hline Source of Variation & $\mathbf{d k}$ & JK & KT & Fo & Ft \\
\hline Average & 1 & 2057,93 & 2057,93 & & \\
Treatment & & & & & \\
A & 1 & 0,39 & 0,39 & $8,06^{*}$ & 4,09 \\
B & 1 & 0,30 & 0,30 & $6,28^{*}$ & 4,09 \\
AB & 1 & 1,24 & 1,24 & $25,81^{*}$ & 4,09 \\
Error (E) & 36 & 1,73 & 0,05 & & \\
\hline Total & 40 & & & & \\
\hline
\end{tabular}


Differences in Increased Bullet Resistance Capability between Plyometric Training Methods and Conventional Overall

Based on the analysis of variance (ANAVA) at a significant level $\alpha=0.05$, obtained $\mathrm{Fo}=8.06$ and $\mathrm{Ft}=4.09$. The summary can be seen in Appendix 9 page 127. The calculations can be seen in Appendix 9 page 128. Thus Fo> Ft, so that Ho is rejected, it can be concluded that overall, there are significant differences between conventional and plyometric training methods for increasing shot put capability. In other words, increasing the ability to reject a shot by using the plyometric training method $(=7.27$; $\mathrm{s}=0.31)$ is better than conventional training methods $(=7.08 \mathrm{~s}=0.20)$. This means a research hypothesis which states that overall the increase in shot put capability by using plyometric training methods is better than using conventional methods.

\section{Differences in the Effects of Plyometric Training Methods and Conventional} Training Methods on Increasing Bullet Resistant Capabilities for High Achievement

\section{Motivation Groups.}

Plyometric training methods have an effect on increasing shot put ability in groups with high achievement motivation.

Table 5; Group Comparison of Plyometric and Conventional Training Methods in High Achievement Motivation.

$\frac{\text { No }}{2} \frac{\text { Compared groups }}{\mathrm{P}_{1} \text { dengan } \mathrm{P}_{2}} \frac{\text { Q count }}{6,16} \frac{\text { Q table }}{2.26} \frac{\text { Description }}{\text { Signifikan }}$

The high achievement motivation treatment group with the plyometric training method (P1) compared to the high achievement motivation treatment group with conventional training methods $(\mathrm{P} 2)$, obtained $\mathrm{Qo}=6.16$ and $\mathrm{Qt}=2.26$. Thus $\mathrm{Qo}$ is greater than Qt, so Ho is rejected, and it can be interpreted that there is a significant difference in the increase in shot put capability between the plyometric and conventional training methods for high-achieving motivation groups. In other words, students who have high achievement motivation using the plyometric training method $(=7.48 ; \mathrm{s}=$ $0.22)$ are better than conventional training methods $(=7.04 ; \mathrm{s}=0.22)$ in bullet-reject ability. Thus the research hypothesis states that high achievement motivation with 
plyometric training methods is better than conventional training methods in shot put capability.

\section{Differences in the Effects of Plyometric Training Methods and Conventional Exercise Methods on Increasing Bullet Resistant Capabilities for Low Achievement Motivation Groups}

Training methods have a significant effect on increasing shot put ability in groups that have low achievement motivation. This is proven based on the results of further tests in analysis of variance (ANAVA) using the Tukey test whose results are as follows:

Table 6; Group Comparison of Plyometric and Conventional Training Methods in Low Achievement Motivation.

\begin{tabular}{crccl}
\hline No & Compared groups & Q count & Q table & Description \\
\hline 3 & $\mathrm{P}_{3}$ with $\mathrm{P}_{4}$ & 0,54 & 2,26 & Not Significant
\end{tabular}

The low achievement motivation treatment group with the plyometric training method (P3) compared to the low achievement motivation treatment group with the conventional training method $(\mathrm{P} 4)$, obtained $\mathrm{Qo}=0.54$ and $\mathrm{Qt}=2.26$. In other words, athletes who have low achievement motivation using conventional training methods $(=7.11 \mathrm{~s}=0.19)$ are better than plyometric training methods $(=7.07 ; \mathrm{s}=0.24)$ in increasing shot put ability . Thus Qo is smaller than Qt, so Ho is accepted or there is no significant difference.

\section{Interaction Between Training Methods and Achievement Motivation Towards Increased Bullet Resistant Ability}

Based on the results of analysis of variants about the interaction between the training methods and achievement motivation for increasing shot put ability seen in the Anava calculation table above, that the price calculation Fo interaction $(\mathrm{FAB})=25.82$ and $\mathrm{F}$ table $=4.09$ It appears that the function $\mathrm{F}$ count $>\mathrm{F}$ table , so Ho was refused. The conclusion is that there is an interaction between the training method and achievement motivation towards the shot put capability. 
Table 7. Summary of Tukey Test Calculation Results

\begin{tabular}{ccccc}
\hline No & Compared groups & Q count & $\begin{array}{c}\text { Q table } \\
\mathbf{A = 0 . 0 5}\end{array}$ & Description \\
\hline 1 & P1 with P2 & 6,16 & 2,26 & Significant \\
2 & P3 with P4 & 0,54 & 2,26 & Not significant \\
\hline
\end{tabular}

Interaksi antara metode latihan dengan motivasi berprestasi dalam pengaruhnya terhadap kemampuan tolak peluru dapat divisualisasikan secara grafis seperti tampak pada gambar di bawah ini.

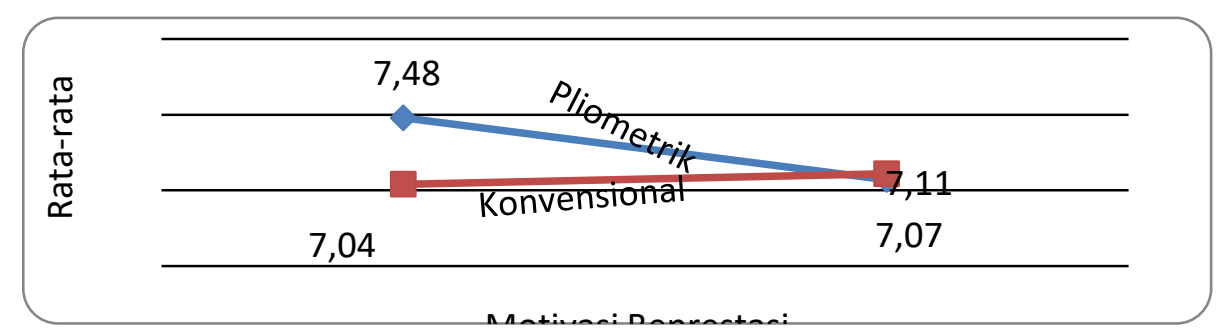

Figure 1. Interaction between training methods and achievement motivation towards the ability to put out a bullet

\section{DISCUSSION}

Based on the results of the analysis of research data conducted, the results obtained that the research hypothesis which states that the ability of Shot Put between students trained with plyometric training methods is better than students trained with conventional training methods as a whole is correct. This means that overall there is a significant difference between the plyometric training method and the conventional training method on the ability to reject shot. The results of the second hypothesis (two) show that there are differences for students who have high achievement motivation, and students who have low motivation, namely the plyometric training method is better than the conventional training method for the ability to reject shot. Based on the results of the field evidences in the third hypothesis (three) prove that students who have low achievement motivation, there is no significant difference between plyometric training methods and conventional methods, thus students who have low achievement motivation in performing the ability to reject bullets using either method Plyometric and conventional exercises are relatively the same. The fourth (four) hypothesis testing is the 
interaction between the training method and achievement motivation towards the ability to reject bullets. Thus there is a significant interaction between the training methods and achievement motivation on the ability to Repel bullets.

\section{CONCLUSION}

The study used an experimental method that involved independent variables, namely the method of training and achievement motivation, while the dependent variable was the ability to reject bullets. Based on the data obtained, the results of hypothesis testing and discussion of research results can be concluded that: 1).Overall there is a significant difference between the plyometric training method and the conventional training method on the ability to reject bullets. 2). For athletes who have high achievement motivation, plyometric training methods are better than conventional training methods on the ability to reject bullets. 3). For athletes who have low achievement motivation, there is no significant difference between plyometric training methods and conventional training on the ability to reject shot. 4). There is a positive interaction between the training method and achievement motivation towards the shot put capability.

\section{REFERENCE}

Gene V. Glass and Kenneth D. Hopkins, (1984) Statistical Methods in Education and Psychology, Englewood Cliffs: Printice Hall,

Chu. Donald A. (1992) Jumping Into Plyometrics. California: Ather Sport Injury Clinic Castro Valley.

D.D Amheim, (1985) Modern Principles Of Athletic Training. Philladelphia: CV Molby Company.

Devries, Herbart, A., Terry J. Housh. (1994) Physiology of Exercise. Dubuque Lowa: WCB. Brown \& Benchmark Publishers.

Fox, Edward L. and Richard w, Bowers, Merle L Foss, (1991) Physiological Basic of Physical Education and Athleties. Philladephia: Sauders College Publishing, 1991.

----------, Sport Physiology, (1992) Dubuque: Wm.C. Brown.

Gunarsa S. (1989) Sport Psychologi Jakarta: PT. BPK Gunung Mulia.

Harsono. Coaching and Psychological Aspects in Coaching. Jakarta: Tambak Kusuma, 1988.

IAAF, Basic Guidelines for Training Athletics, Jakarta: PASI, 1993

------, Teaching Guidelines for Running, Jumping, Throwing, Jakarta: PASI, 2000 
K Engkos, Physical education and Health Sciences.Jakarta: Erlangga, 1994

Koeswara E. (1989) Motivation Theory and Research,Bandung: Angkasa.

Monty P.S. (2000) Fundamentals of Sport Psychology, Jakarta: Pustaka Sinar Harapan.

Murwarni S. (2001) Applied Statistics (Data Analysis Techniques),Jakarta: Program Pasca Sarjana UNJ.

Soebroto, M. (2004) Physical Education Theory.Bandung: Yayasan Nuasnsa Cendekia, PASI. (1991). Athletic Judging and Judging, Jakarta: PT. Enka Parahiyangan.

Purwanto N, (1997). Education Psychology,Bandung: PT. Remaja Rosdakarya.

Pyke, Frans S. (Ed). Better coaching: methods and effects of strength, speed, power, and flexibility training. Camberra: Australia coaching council incorporated,1991.

Richard, W. Bowers \& Edward L. Fox , (1990) Spoprt physiology. Dubuque Lowa: Wm. C Browns, 1992

Rushall, Brent S. \& Frank S Pyke. Training For Sport and Fitness Melbourne South: The Macmillan Company of Australia PTY LTD.

Russel, R., Clenaghan, P., Rotella, R. (1993). Scientific Foundations of Coachin. Terjemahan Kasiyo Dwijowinoto, Semarang : IKIP Semarang.

Setyobroto S, (1993) Coaching Psycholog, Jakarta: CV. Jaya Sakti.

Sharkey, Brian J. (2003) Fitness and Health. Terjemahan Eri Desmarini Nasution, Jakarta: PT Raja Grafindo Persada.

Sukintaka. (2004) Physical Education Theory. Bandung: Yayasan Nuansa Cendekia.

Sudjana, (1989) Statistical Method, Bandung: Tarsito.

---------, (2002) Design and Experiment Analysis, Edisi IV, Bandung: Tarsito,

Suryobroto,S. Sport Psychology, (1989). Jakarta: PT. Anen Kosong Anem.

Wasty. (1987) Education Psychology Jakarta: PT. Bina Aksara.

Thomas R Baechle. \& Earle Roger W, (2002) Fitness Weight Training, Terjemahan Razi Siregar, Jakarta: Raja Grafindo Persada.

, (1997) Weight Training, Jakarta: Raja Grafindo Persada.

Verducci, F M, (1980) Measurement Concept in Physical Education, St, Louis: Mosby Company. 